\title{
Agroecology and Uses of Galinsoga parviflora as Indigenous Vegetable in Highland of Kuningan, Banjarnegara and Wonosobo, Indonesia
}

\section{Agroekologi dan Pemanfaatan Galinsoga parviflora sebagai Sayuran Indigenous di Dataran Tinggi Kuningan, Banjarnegara dan Wonosobo, Indonesia}

\author{
Edi Santosa ${ }^{*}$, Sofyan Zaman ${ }^{1}$, Dwi Guntoro ${ }^{1}$, and Anas Dinurrohman Susila ${ }^{1,2}$ \\ ${ }^{1}$ Department of Agronomy and Horticulture, Bogor Agricultural University \\ Jl. Meranti, Kampus IPB Dramaga, Bogor 16680, Indonesia \\ ${ }^{2}$ Center for Horticulture Studies, Bogor Agricultural University \\ Kampus IPB Baranangsiang Bogor 16144, Indonesia
}

Received 2 November 2020/Accepted 10 December 2020

\begin{abstract}
Gallant soldier (Galinsoga parviflora Cav.) is a cosmopolitan weed and is traditionally used as a vegetable in Java highland. The study aimed to evaluate agroecology and uses of $\underline{G}$. parviflora as an indigenous vegetable in Java. Researches were conducted in Kuningan, Banjarnegara, and Wonosobo districts from June 2015 to July 2017. The distribution map was drawn from field tracks, interviews, and literature studies. Results revealed two Galinsoga species based on leaf and stem shape, i.e., $\underline{G}$. parviflora and $\underline{G}$. quadriradiata. Only $\underline{G}$. parviflora was selected as a vegetable in Banjarnegara and Wonosobo, but not in Kuningan district. It ranked seventh among 13 traditional vegetables; young shoot with inflorescences was consumed after cooking or boiling, and sometimes used as a diuretic. Although it contributed low to household diet, however, its position on the social relationship among neighbors was important. The wide distribution range of Galinsoga in Java is potential as a new vegetable. It is important to study the nutrient content of this vegetable to improve utilization.
\end{abstract}

Keywords: Asteraceae, Dieng, gallant soldier, jukut saminggu, weed

\section{ABSTRAK}

Mondreng (Galinsoga parviflora Cav.) adalah gulma kosmopolitan dan secara tradisional digunakan sebagai sayuran di dataran tinggi Jawa. Penelitian bertujuan mengevaluasi agroekologi dan pemanfaatan $\underline{G}$. parviflora sebagai sayuran indigenous di Jawa. Penelitian dilakukan di Kabupaten Kuningan, Banjarnegara, dan Wonosobo dari Juni 2015 hingga Juli 2017. Peta distribusi diambil dari penelusuran lapangan, wawancara, dan studi literatur. Hasil penelitian menunjukkan ada dua spesies Galinsoga berdasarkan daun dan batang, yaitu $\underline{G}$. parviflora dan $\underline{G}$. quadriradiata. $\underline{G}$. parviflora merupakan sayuran di Kabupaten Banjarnegara dan Wonosobo, tetapi tidak di Kabupaten Kuningan. Galinsoga termasuk satu dari 13 jenis sayuran tradisional; pucuk muda dengan bunga dikonsumsi setelah dimasak atau direbus, dan kadang-kadang digunakan sebagai diuretik. Sayuran Galinsoga berkontribusi rendah terhadap rumah tangga, namun peranannya dalam hubungan sosial antar tetangga relatif penting. Perlu dilakukan studi kandungan nutrisi untuk meningkatkan pemanfaatannya.

Kata kunci: Asteraceae, Dieng, gulma, jukut saminggu, mondreng

\section{INTRODUCTION}

French soldier or gallant soldier (Galinsoga parviflora Cav.; $2 \mathrm{n}=16$; Asteraceae) is a native plant to Peru (Canne, 1983; Rai and Tripathi, 1984; Damalas, 2008; Oh et al., 2010; Shin et al., 2012; Surywanshi and Yadava, 2015). In Indonesia, Galinsoga parviflora is called by several names such as batakacut, bribil, jukut saminggu, and mondreng (Setyawati et al., 2015). The genus comprises 14 species

\footnotetext{
* Corresponding author. e-mail: edisang@gmail.com
}

mainly found in Mexico, and Central and South America; except G. parviflora and G. ciliata (Raf.) Blake which has been naturalized worldwide (Shin et al., 2012). They are mostly found in high altitudes (Jang et al., 2014). $G$. parviflora is known as an invasive, sympatric, and cosmopolitan weed in agriculture fields (Rai and Tripathi, 1984; Oh et al., 2010; Shin et al., 2012; Surywanshi and Yadava, 2015).

The plant is non-toxic and is used as a fodder for cattle (Ali et al., 2017). The shoot including leaves, stem, and the flower is used as a traditional vegetable in Zimbabwe and South America (Chipurura et al., 2013; Maroyi, 2013; 
Patharaj and Kannan, 2019), anti-inflammatory and wound healing of dermatological diseases, eczemas, lichens and snakebites (Bazylco et al., 2015; Patharaj and Kannan, 2019). It is a good source of phenolic acids, which can be useful for the prevention of cardiovascular and other chronic diseases (Chipurura et al., 2013). G. parviflora is a good source of magnesium and protein (Odhav et al., 2007). According to Odhav et al. (2007), $100 \mathrm{~g}$ fresh mass contains $41.0 \mathrm{kcal}, 89.0 \mathrm{~g}$ moisture, $4.0 \mathrm{~g}$ protein, $0.5 \mathrm{~g}$ fat, $1.2 \mathrm{~g}$ fiber, $1.7 \mathrm{~g}$ ash, $5.3 \mathrm{~g}$ carbohydrate, $17.8 \mathrm{mg}$ calcium, $4.2 \mathrm{mg}$ phosphorus, $4.0 \mathrm{mg}$ potassium, $4.8 \mathrm{mg}$ mangan, 0.3 mg cuprum, $1.5 \mathrm{mg}$ zink, $74.9 \mathrm{mg}$ magnesium, and $3.0 \mathrm{mg}$ iron. Phytochemical evaluation by Patharaj and Kannan (2019) shows the plant extract contains an alkaloid, phenol, flavonoid, sterol, and terpenoids indicating great medicinal properties. In Indonesia, the G. parviflora exists in Sumatra and Java islands (Perdana et al., 2013; Surywanshi and Yadava, 2015). People in central Java use the shoot as a vegetable, however, the report was rare.

Studies on indigenous vegetables are mostly based on their association with limited community access to commercial vegetables, including the famine situation of middle-low income families (Leonti, 2012). The indigenous vegetables are commonly traded locally and they become an important part of food security, traditional medicine, nutrition, and source of income (Adhav et al., 2007; Andarwulan et al., 2012; Cruz-Garcia and Price, 2012; Leonti, 2012; Maroyi, 2013; Bazylco et al., 2015). Santosa et al. (2015) has indicated increasing consumer interest in non-pesticide vegetables and ethnic vegetables in West Java. The present study aimed to evaluate agroecology and uses of Galinsoga parviflora as an indigenous vegetable in Java.

\section{MATERIALS AND METHODS}

\section{Study Sites}

Fieldwork was carried out in Kuningan district around Mt. Ciremai of West Java, and Banjarnegara and Wonosobo districts around Mt. Dieng of Central Java (Figure 1) from June 2015 to July 2017. These districts were considered as potential gathering places of the Galinsoga species based on the preliminary evaluation. Mt Dieng area known as Dieng Plateau, is the center of vegetable production in Central Java, while Mt Ciremai in Kuningan is one of the centers of vegetable production in West Java. Ten villages were evaluated, i.e., Cisantana and Kuningan (Kuningan District), Sembungan and Garung-Menjer (Wonosobo District), and Binangun, Leksana, Kubang, Kepakisan, Pekasiran, and Surenan villages (Banjarnegara district) (Table 1). These villages represented the main center of vegetable production in each district.

\section{Data Collection}

Galinsoga specimen was evaluated according to Kabuce and Priede (2010). The specimen was considered as Galinsoga parviflora Cav group that had soft/rare or without hairs on the stem, leaves, or peduncle irrespective of single, double, or 3 toothed ray florets, and leaf margin less serrate or smooth. Otherwise, it was Galinsoga quadriradiata Ruiz \& Pav group if the stem, leaves, and peduncle had coarse hairs, 4-5 white and 3 toothed ray florets, and serrate leaf margin.

In each village, Galinsoga was observed at different sites: 1) intensive-cultivated fields (farm and home garden); 2) least intensive-cultivated fields (under the canopy of perennial plants); 3) uncultivated fields (fallow lands, conservation lands, and pastures); 4) ruderal areas (roadsides, paths, and farm tracks); and 5) aquatic environments (ponds, gutter, streams, water reservoirs, and irrigation ditches near farmlands). In each site (when available), three to four plots (seized about $20 \mathrm{~m}$ x $20 \mathrm{~m}$ of each) were separated by about $0.1-0.5 \mathrm{~km}$ were visited.

In each village, at least 10 farmers were interviewed using open questions. The farmers were determined based on the field survey following the main road in the village of different hamlet. In each hamlet, 3-4 farmers working in the field were visited randomly and interviewed. The culture
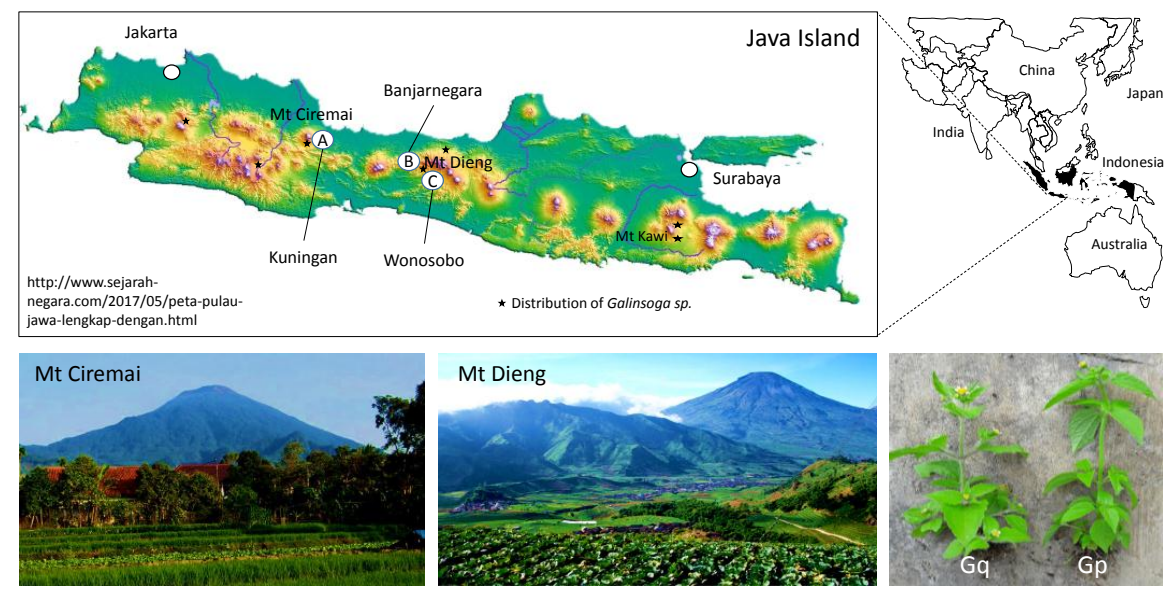

Source: www.kaskus.co.id

Source: blog.ivacanza.co

Figure 1. Study site of Kuningan (A), Banjarnegara (B), Wonosobo Districts (C) and Galinsoga sp distribution in Java. View around Mt. Ciremai and Mt. Dieng. Gq-Galinsoga quadriradiata, Gp-Galinsoga parviflora 
Table 1. Description of the study site

\begin{tabular}{llcccccc}
\hline \multirow{2}{*}{ District } & \multirow{2}{*}{ Site } & \multirow{2}{*}{ UTM coordinate } & \multicolumn{2}{c}{ Temp. $\left({ }^{\circ} \mathrm{C}\right)$} & \multirow{2}{*}{ Wet month $^{\mathrm{z}}$} & \multirow{2}{*}{ Rainfall $(\mathrm{mm})^{\mathrm{y}}$} & \multirow{2}{*}{ Altitude $(\mathrm{m})^{\mathrm{x}}$} \\
\cline { 5 - 6 } Kuningan & CI & $-6.94330,108.43589$ & $17-20$ & $22-25$ & 9 & 2,230 & 1,116 \\
& KU & $-6.98590,108.47436$ & $22-24$ & $30-33$ & 8 & 2,230 & 510 \\
Banjarnegara & BI & $-7.26296,109.71419$ & $18-22$ & $25-29$ & 8 & 2,157 & 1,025 \\
& LE & $-7.26924,109.74151$ & $18-22$ & $25-29$ & 8 & 2,157 & 1,026 \\
& KB & $-7.27289,109.74591$ & $18-22$ & $25-29$ & 8 & 2,157 & 1,002 \\
& KP & $-7.19728,109.88588$ & $8-10$ & $17-19$ & 8 & 2,650 & 1,944 \\
& PK & $-7.19020,109.85278$ & $8-10$ & $17-19$ & 8 & 2,650 & 1,901 \\
\multirow{5}{*}{ Wonosobo } & SU & $-7.19720,109.85672$ & $8-10$ & $17-19$ & 8 & 2,650 & 1,774 \\
& SE & $-7.23683,109.92387$ & $8-10$ & $17-19$ & 8 & 2,650 & 2,160 \\
& GA & $-7.27229,109.92103$ & $18-20$ & $25-27$ & 10 & 4,088 & 1,240 \\
\hline
\end{tabular}

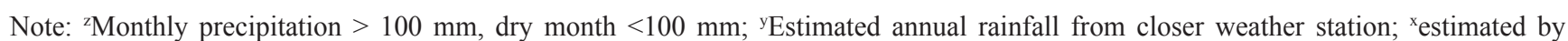
Mapfinder software; BI-Binangun, CI-Cisantana, GA-Garung Menjer, PK-Pekasiran, KB-Kubang, KU-Kuningan, LE-Leksana, KPKepakisan, SE-Sembungan, SU-Surenan village

technique was determined through an interview with farmers with farms seized 0.25 ha or larger. The production rate per hectare was estimated by converting the average yield of a 25 meter square plot into a land size of $10,000 \mathrm{~m}^{2}$. The yield of a plot could be overestimated due to the variation in species of the main crop, and agriculture techniques including manure and mulch applications. Harvesting time was determined when the first terminal flower bloomed; harvesting followed farmer practice. The uses of harvested Galinsoga was rank altogether with other indigenous vegetables, i.e., selling to market, self-consumption, fulfill family nutrition, social function as a gift to other families, exchanged vegetables with other families, and others including as a feed. The method follows Santosa et al. (2003). Before the interview, we listed the thirteen most common traditional vegetables based on previous information from selected farmers.

Consumption rates were evaluated through an interview with 10-16 middle-up income consumers in each village. The respondent had a monthly income of 5 million rupiahs (about US\$ 500) or more, considering they had an independent decision to consume the indigenous vegetable, unlike low-income consumers. The consumers also relatively well-educated (senior high school or higher), open-minded, and had a broad social relationship. The respondents included government officers $(6.8 \%)$, businessmen $(6.8 \%)$, merchants $(8.5 \%)$, public service $(7.7 \%)$, farmers $(55.6 \%)$, and others (14.5\%); and some consumers had more than one job. The consumer preference was asked on 13 traditional vegetables similar list to the farmer interview using simple method follows Santosa et al. (2003) and Kolli et al. (2016). In brief, respondents ranked the vegetables from 1 to 13 , with 1 as the most preferable and 13 as the last. In case the respondent did not familiar with particular species, it was omitted from the calculation. Based on the average rank denoted by respondents in a village, then a new rank of the vegetables was developed representing the village preference.
In each district, a subdistrict market close to targeted villages was visited, and the availability of indigenous vegetables was recorded. In each market, 5-10 vegetable merchants were randomly interviewed. A vegetable was classified as marketable if a merchant at least traded it once a year.

\section{RESULTS AND DISCUSSION}

Uses

Galinsoga is locally called anoni (Kuningan), and jangkung and ndosmen (Banjarnegara and Wonosobo Districts). Two species were found in all sites, i.e., $G$. quadriradiata (hairy) and G. parviflora (smooth) (Figure 1). Only G. parviflora predominantly was consumed; the shoot was used as a vegetable in Banjarnegara and Wonosobo Districts but never been consumed in Kuningan District (Table 2). Farmers and consumers preferred species based on bright green leaf with soft/rare hair/ hairless and weak pungency referred to G. parviflora. They refused to harvest G. quadriradiata because of hairy leaves.

Among local vegetables, the consumer preference for Galinsoga ranked 6.5 (Table 2). It was likely that higher preference for Galinsoga consumption in Sembungan and Binangun villages due to the higher availability of the plant among the study sites. Conversely, in the lower altitude villages such as Leksana and Garung where the Galinsoga was less abundant, the Galinsoga only was consumed rarely depend on the availability.

In Pekalongan, a district nearby Banjarnegara, people boiled Galinsoga plant and drank the water as a tea for a diuretic. Similarly, people in Banjarnegara claimed Galinsoga tea had diuretic and refreshment effects. Freshness feeling after drink the tea of G. parviflora could relate to the antioxidants content, as stated by Odhav et al. (2007). Bazylco et al. (2015) determined caffeoylglucaric acids and 
Table 2. Rank of indigenous vegetables by consumer preference in Kuningan, Banjarnegara, and Wonosobo districts

\begin{tabular}{|c|c|c|c|c|c|c|c|c|c|c|c|c|}
\hline \multirow{2}{*}{ No } & \multirow{2}{*}{ Vegetable (Family/Common/local name) } & \multicolumn{2}{|c|}{ Kuningan } & \multicolumn{6}{|c|}{ Banjarnegara } & \multicolumn{2}{|c|}{ Wonosobo } & \multirow{2}{*}{$\begin{array}{l}\text { Avg. } \\
\operatorname{rank}^{z}\end{array}$} \\
\hline & & $\mathrm{CI}$ & $\mathrm{KU}$ & $\mathrm{LE}$ & $\mathrm{KB}$ & $\mathrm{BI}$ & $\mathrm{KP}$ & PK & $\mathrm{SU}$ & $\mathrm{SE}$ & GA & \\
\hline 1 & $\begin{array}{l}\text { Carica papaya Linn. (Caricaceae/papaya/ } \\
\text { gandul) }\end{array}$ & 7 & 7 & 5 & 9 & 4 & 3 & 4 & 5 & 7 & 6 & 5.7 \\
\hline 2 & $\begin{array}{l}\text { Centella asiatica } \text { L. (Apiaceae/Indian } \\
\text { pennywort/Pegagan) }\end{array}$ & 9 & 8 & 9 & 13 & 11 & - & - & - & 11 & 12 & 10.4 \\
\hline 3 & $\begin{array}{l}\text { Cosmos caudatus Kunth (Asteraceae/wild } \\
\text { cosmos/Kenikir) }\end{array}$ & 3 & 6 & 11 & 8 & 10 & 8 & 8 & 8 & 10 & 9 & 8.1 \\
\hline 4 & $\begin{array}{l}\text { Emilia sonchifolia (L). DC ex Wight } \\
\text { (Asteraceae /Red tasselflower/Lengko) }\end{array}$ & - & - & 13 & 10 & 12 & - & - & - & 12 & 13 & 12 \\
\hline 5 & $\begin{array}{l}\text { Galinsoga parviflora Cav (Asteraceae } \\
\text { /Gallant soldier/Jangkung) }\end{array}$ & - & - & 8 & 7 & 5 & 6 & 6 & 6 & 3 & 11 & 6.5 \\
\hline 6 & $\begin{array}{l}\text { Limnocharis flava (L.) Buchenau } \\
\text { (Limnocharitaceae/Velvet leaf/Genjer) }\end{array}$ & 5 & 3 & 12 & 11 & - & - & - & - & - & 4 & 7 \\
\hline 7 & $\begin{array}{l}\text { Manihot esculenta Crantz (Euphorbiaceae/ } \\
\text { casava/kopral) }\end{array}$ & 6 & 9 & 3 & 3 & 2 & 5 & 7 & 3 & 8 & 3 & 4.9 \\
\hline 8 & $\begin{array}{l}\text { Nasturtium officinale R. Br (Brassicaceae/ } \\
\text { Watercress/Kenci) }\end{array}$ & 8 & 2 & 6 & 4 & 6 & 9 & 9 & 10 & 4 & 2 & 6 \\
\hline 9 & $\begin{array}{l}\text { Ocimum basilicum L. (Lamiaceae/Basil/ } \\
\text { kemangi) }\end{array}$ & 2 & 1 & 10 & 12 & 7 & 10 & 10 & 9 & 9 & 10 & 8 \\
\hline 10 & $\begin{array}{l}\text { Sechium edule (Jacq.) Sw. (Cucurbitaceae/ } \\
\text { Chayote/Lung waluh) }\end{array}$ & 1 & 4 & 1 & 2 & 3 & 1 & 1 & 1 & 1 & 1 & 1.6 \\
\hline 11 & $\begin{array}{l}\text { Solanum nigrum Mill. (Solanaceae/ } \\
\text { nightshade/Ranti kebo) }\end{array}$ & 4 & 5 & 2 & 1 & 1 & 2 & 2 & 2 & 2 & 5 & 2.6 \\
\hline 12 & $\begin{array}{l}\text { Xanthosoma sagittifolium (L.) Schott. } \\
\text { (Araceae/Elephant ear/Lumbu putih) }\end{array}$ & - & - & 4 & 5 & 8 & 4 & 3 & 4 & 5 & 7 & 5 \\
\hline 13 & $\begin{array}{l}\text { Xanthosoma sagittifolium (L.) Schott. } \\
\text { (Araceae/Elephant ear/Lumbu ireng) }\end{array}$ & - & - & 7 & 6 & 9 & 7 & 5 & 7 & 6 & 8 & 6.9 \\
\hline
\end{tabular}

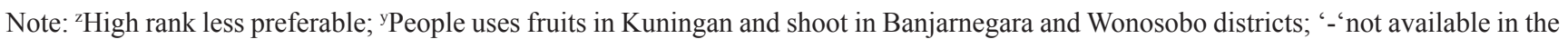
market, not familiar or not for consumption. BI-Binangun, CI-Cisantana, GA-Garung, PK-Pekasiran, KB-Kubang, KU-Kuningan, LE-Leksana, KP-Kepakisan, SE-Sembungan, SU-Surenan village

flavonoids such as patulitrin, quercimeritrin, quercitagetrin, phenolic acids-caffeic and chlorogenic acids; and Dudek et al. (2016) determined the caffeoyl-altraric acid derivatives from Galinsoga leaves.

Many farmers refused to harvest Galinsoga and other indigenous vegetables in their farms because it had a low market value, high cost of collection, and the amount was a little. Therefore, farmers mostly used indigenous vegetables for self-consumption (Table 3). However, it was not aimed to fulfill family nutrition. In Leksana and Kubang villages, some farmers utilized the Galinsoga shoot altogether with Emilia sonchifolia as a feed of rabbit, guinea pig (locally called marmut), and goat; like in Uganda (Mwesigwa et al., 2015) where Galinsoga is utilized as a feed of chicken.

\section{Trading and Consumption}

Galinsoga shoot was available in the local market irregularly. Most vegetable merchants replied that they were able to provide it by request five days in advance, except the merchants in Kuningan market who did not recognize the Galinsoga as a vegetable. A merchant in a market of Karangkobar subdistrict sold 5 to $7 \mathrm{~kg}$ Galinsoga shoot in a day by request in advance. She bonded 40 to 50 shoots into a bunch of about 0.4 to $0.5 \mathrm{~kg}$ (called unting) fetch Rp 500-1,000 (equal to US\$ 0.05-0.10). Vegetable price was unlikely to be a constrain for respondents in Banjarnegara and Wonosobo districts. The price was considered low as compare to pak choi vegetable, Rp 1500-2000 (equal to US\$ 0.15-0.2) for one bunch.

A family with 2-3 members prepared two bunches or more for one serving. Before cooking, the shoots were cleaned by removing the old stem and mature flowers, leaving about 35 to $50 \%$ edible portion based on the weight of a bunch available in the market. Consumers avoided old shoot or full blooming florets because tasted pungent, irrespective of the hairy level.

Some families in Leksana village bought an extra amount and shared it with neighbors or relatives. Sharing food is a common practice among neighbors in mountainous 
Table 3. Farmer's reason to harvest Galinsoga parviflora and other indigenous vegetables in Banjarnegara, Kuningan, and Wonosobo districts

\begin{tabular}{|c|c|c|c|c|c|c|c|}
\hline No & Vegetables $^{Z}$ & $\begin{array}{l}\text { Sell to } \\
\text { market }\end{array}$ & $\begin{array}{c}\text { Self- } \\
\text { consumed }\end{array}$ & $\begin{array}{l}\text { Fulfill } \\
\text { family } \\
\text { nutrition }\end{array}$ & $\begin{array}{l}\text { Social } \\
\text { function } \\
\text { (gift) }\end{array}$ & $\begin{array}{c}\text { Exchanged } \\
\text { with other } \\
\text { families }\end{array}$ & Other $^{Y}$ \\
\hline 1 & C. papaya & 4 & 1 & 3 & 2 & 5 & 6 \\
\hline 2 & C. asiatica & 3 & 2 & 6 & 4 & 5 & 1 \\
\hline 3 & C. caudatus $^{X}$ & 6 & 1 & 3 & 5 & 4 & 2 \\
\hline 4 & E. sonchifolia & 6 & 3 & 5 & 4 & 2 & 1 \\
\hline 5 & G. parviflora & 5 & 1 & 6 & 2 & 3 & 4 \\
\hline 6 & L. flava ${ }^{X}$ & 2 & 1 & 5 & 3 & 4 & 6 \\
\hline 7 & M. esculenta & 2 & 1 & 4 & 3 & 5 & 6 \\
\hline 8 & N. officinale & 1 & 4 & 5 & 2 & 3 & 6 \\
\hline 9 & O. basilicum & 2 & 3 & 4 & 6 & 5 & 1 \\
\hline 10 & S. edule & 1 & 2 & 3 & 4 & 5 & 6 \\
\hline 11 & S. nigrum $^{T}$ & 2 & 1 & 5 & 3 & 4 & - \\
\hline 12 & $X$. sagittifolium- Lumbu & 2 & 1 & 6 & 4 & 5 & 3 \\
\hline \multirow[t]{2}{*}{13} & $X$. sagittifolium- Lumbu ireng ${ }^{\mathrm{V}}$ & 2 & 1 & 3 & 6 & 5 & 4 \\
\hline & Average & 2.9 & 1.7 & 4.5 & 3.7 & 4.2 & 3.8 \\
\hline
\end{tabular}

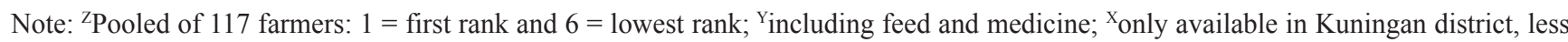
available in other districts; ${ }^{\mathrm{v}}$ consumed by some respondents in Karangkobar subdistrict, but only available in Kalibening subdistrict market; ${ }^{\mathrm{T}}$ fruit in Kuningan district, and shoot in Banjarnegara and Wonosobo districts

Banjarnegara and Wonosobo districts as part of social relationships. Half of the respondents consumed Galinsoga monthly, followed by every six months (Table 4). Galinsoga was mostly consumed as a traditional salad (80\%) followed by soup $(20 \%)$. As a traditional salad, the shoot was initially boiled for about 5-10 minutes and the water was discharged to remove pesticide residue. It was consumed as urap (mixed with shredded coconut and paste of candlenut, garlic, onion, chili, coconut sugar, and salt) or simply with chili paste (sambal). The Galinsoga soup was prepared with leaves of cassava, nightshade, and pak choi. It was stir-fried with herb paste made of galanga, garlic, salt, fried onion and served when it still hot.

\section{Economic Value and Agroecology}

Galinsoga was an important weed in the vegetable fields of leek, cabbage, carrot, chilly, tomato, and pak choi

Table 4. Frequency on galinsoga intake among respondents upon availability in the market

\begin{tabular}{|c|c|c|c|c|c|c|}
\hline \multirow{2}{*}{ District } & \multirow{2}{*}{$\begin{array}{l}\text { Village } \\
\text { name }\end{array}$} & \multicolumn{4}{|c|}{ Preference for consumption (percentage) ${ }^{Z}$} & \multirow{2}{*}{$\begin{array}{c}\text { Total } \\
\text { respondents }\end{array}$} \\
\hline & & Weekly & Monthly & 6-monthly & Annually & \\
\hline \multirow[t]{2}{*}{ Kuningan } & Cisantana & - & - & - & $-\mathrm{Y}$ & 10 \\
\hline & Kuningan & - & - & - & $-Y$ & 12 \\
\hline \multirow[t]{6}{*}{ Banjarnegara } & Binangun & $2(17)$ & $7(58)$ & $3(25)$ & - & 12 \\
\hline & Leksana & $1(6)$ & $12(75)$ & $3(19)$ & - & 16 \\
\hline & Kubang & - & $8(80)$ & $2(20)$ & - & 10 \\
\hline & Kepakisan & $1(8)$ & $6(50)$ & $3(25)$ & $2(17)$ & 12 \\
\hline & Pekasiran & - & $7(54)$ & $6(46)$ & - & 13 \\
\hline & Surenan & - & $3(27)$ & $6(55)$ & $2(18)$ & 11 \\
\hline \multirow[t]{3}{*}{ Wonosobo } & Sembungan & - & $6(60)$ & $4(40)$ & - & 10 \\
\hline & Garung & - & $5(46)$ & $5(46)$ & $1(8)$ & 11 \\
\hline & Average $(\%)$ & 3.8 & 56.3 & 34.5 & 5.4 & \\
\hline
\end{tabular}

Note: ${ }^{\mathrm{z} C o n s u m e d ~ a s ~ s a l a d, ~ p e c e l, ~ s o u p, ~ o r ~ m i x e d ~ w i t h ~ o t h e r ~ v e g e t a b l e s ; ~}{ }^{\mathrm{Y}}$ most respondents want to try to consume 
fields such as in Kepakisan and Pekasiran villages (Table 5). In Garung village, some farmers maintained Galinsoga in the home garden as a vegetable, although it was claimed as a weed in home gardens of banana in Leksana village. The Galinsoga existed under the canopy of terong mener (Solanum betaceum Cav.) and papaya (Carica papaya) fields in Sembungan, Pekasiran, and Kepakisan villages, therefore, the Galinsoga became dominant weeds in the Dieng area, irrespective of crops. According to Setyawati et al. (2015), G. parviflora predominantly grows in the open area and disturbed ground.

Many farmers in Kepakisan, Pekasiran, and Surenan villages claimed Galinsoga as an indicator plant of fertile soil, and help to control soil erosion. According to Guo et al. (2008) leachate of $G$. parviflora could accelerate germination and seedling growth of Brassica pekinensis, although aqueous leaf extract at rate $80 \mathrm{~g} \mathrm{~L}^{-1}$ inhibits the seeds germination and seedling growth of Raphanus sativus, Brassica chinensis, and Lactuca sativa var romana. Some farmers maintained the Galinsoga as an insect trap crop in the farm of carrot, leek, maize, cabbage, and other Brassicaceae families. According to Yuliadhi et al. (2013), the Galinsoga flower provides a nest site for Diadegma semiclausum, a parasite of Plutella xylostella in the cabbage field. In Malang, Ilmiyah (2015) identified G. parviflora as a host plant for Menochilus sexmaculatus, a predator of Aphis brassicae dan Myzus persicae in cabbage.

According to farmers, growing Galinsoga was simple. It abundant in fertile, high organic matter and well-drained soil with $\mathrm{pH} 4.8$ to 6.0 , however, it also available in less fertile soils. Undisturbed plants able to complete three times a life cycle a year; a life cycle required about three months. During a life cycle, the Galinsoga continuously showered seeds assisted by wind because the seed has pappus. According to Damalas (2008), the plant completes a life cycle within 45-50 days and produces regrowth from stem cutting. In Binangun village, the seedling started to grow in the early rainy season (September); and leaves were harvested around the end of September to November. In Leksana and Kubang villages, seedling available yearround in the field with supplement irrigation. According to Kastanja (2015), G. parviflora becomes a dominant weed within 18 days after soil plowing. According to Ivany and Sweet (1973), the seed germinates within 10 days at a rate of 99.3 to $100 \%$ under sunshine and $90 \%$ in the dark. Therefore, to express its fast coverage after soil plowing, people in Garut district, West Java calls Galinsoga as jukut saminggu (a-week-grass). In Banjarnegara and Wonosobo districts, a mature plant produced 200 to 400 florets, and each floret contained 24 to 50 seeds. Thus, a single plant approximately produced 4,800 to 20,000 seeds in a growing season.

Nevertheless, variability in Galinsoga infestation was found in the field according to microclimate (Table 6). Seedling mostly absent in fallow fields, except in Sembungan, Kepakisan, and Pekasiran villages. On the other hand, the seedling was abundant in intensive and semi-intensive fields, including around the aquatic body in Cisantana, Sembungan, and Kuningan villages that might facilitate seed dispersal into lower altitudes in those villages. Interestingly, many leek fields were free of Galinsoga seedling in Cisantana village-Kuningan. Unfortunately, vegetation analysis was not conducted at the present study therefore factor determined seedling availability among

Table 5. Presence of Galinsoga seedlings at different main crop in each study site

\begin{tabular}{|c|c|c|c|c|c|c|c|c|c|c|}
\hline \multirow{3}{*}{ Crop name } & \multicolumn{10}{|c|}{ Presence of Galinsoga seedling } \\
\hline & \multicolumn{2}{|c|}{ Kuningan } & \multicolumn{6}{|c|}{ Banjarnegara } & \multicolumn{2}{|c|}{ Wonosobo } \\
\hline & $\mathrm{CI}$ & $\mathrm{KU}$ & LE & $\mathrm{KB}$ & $\mathrm{BI}$ & $\mathrm{KP}$ & PK & $\mathrm{SU}$ & $\mathrm{SE}$ & GA \\
\hline Banana & na & na & + & na & - & na & na & na & na & + \\
\hline Beans* & - & - & + & + & + & + & + & + & + & + \\
\hline Cabbage & + & na & + & + & + & + & + & + & + & + \\
\hline Carrot & + & na & na & na & na & + & + & + & + & - \\
\hline Cassava & - & + & + & - & + & na & na & na & na & - \\
\hline Chilli pepper & - & + & + & + & + & na & + & + & na & - \\
\hline Chinese cabbage & + & na & + & + & + & + & + & + & + & - \\
\hline Leek & + & + & + & + & + & + & + & + & + & + \\
\hline Maize & + & - & + & + & + & na & na & na & na & + \\
\hline Pak choi & + & - & - & + & + & + & + & + & + & - \\
\hline Potato & + & na & na & na & na & + & + & + & + & na \\
\hline Sweet potato & + & + & + & + & - & na & na & na & na & - \\
\hline Tomato & + & - & - & + & + & - & + & + & + & - \\
\hline
\end{tabular}

Note: na-no crop during study; '-‘ = absent, '+" = present; * including kacang kapri (Pisum sativum L.) and kacang babi (Vicia faba L). BI-Binangun, CI-Cisantana, GA-Garung, PK-Pekasiran, KB-Kubang, KU-Kuningan, LE-Leksana, KP-Kepakisan, SE-Sembungan, SU-Surenan village 
Table 6. Presence of Galinsoga parviflora in the different microclimate in Kuningan, Banjarnegara, and Wonosobo Districts, Indonesia

\begin{tabular}{lcccccccccc}
\hline \multirow{2}{*}{ Microclimate } & \multicolumn{3}{c}{ Kuningan } & \multicolumn{4}{c}{ Banjarnegara } & \multicolumn{3}{c}{ Wonosobo } \\
\cline { 2 - 10 } & CI & KU & LE & KB & BI & KP & PK & SU & SE & GA \\
\hline Intensive field & +++ & + & ++ & +++ & ++ & +++ & +++ & +++ & +++ & + \\
Less intensive & ++ & - & - & - & + & ++ & ++ & ++ & +++ & - \\
Fallow lands & - & - & - & - & - & + & + & - & + & - \\
Ruderal sites & ++ & + & - & - & - & + & + & + & ++ & - \\
Aquatic side & ++ & + & - & ++ & - & + & + & - & +++ & - \\
\hline
\end{tabular}

Note: BI-Binangun, CI-Cisantana, GA-Garung, PK-Pekasiran, KB-Kubang, KU-Kuningan, LE-Leksana, KP-Kepakisan, SE-Sembungan, SU-Surenan village; '-" not available, + denotes 1 to 10 seedlings, ++ denotes 11 to 50 seedlings, +++ denotes $>50$ seedlings of average three plots sized $5 \mathrm{~m} \times 5 \mathrm{~m}$

microclimate still unresolved. It was noted that at the gutter of vegetable fields in Cisantana village present weeds of Artimisia $s p$ and Eupatorium $s p$. It has been reported that seed germination is sensitive to allelopathy produced by Artemisia dubia (das Mallik et al., 2014) and Eupatorium riparium Regel (Rai and Tripathi, 1984) that may explain the absence of Galinsoga in fallow fields.

\section{Future Challenge}

In the intensive vegetable fields, cropping 3-4 times a year was common in the study sites. In previous cropping time, goat manures at a rate of 20-30 ton ha $^{-1}$ was applied in Banjarnegara and Wonosobo districts, and amounted to 15-20 ton ha ${ }^{-1}$ in Kuningan district. Since farmers feed goats with flowering Galinsoga plants like in Binangun village, therefore, seeds bank was speculated high in goat manure leading to high seedlings growth after the application of the goat manure.

Recently, manure from chicken production had been adopted by approximately $90 \%$ of the vegetable production area in Banjarnegara and Wonosobo districts due to cheap and high availability than that of the goat manure. As a result, in the farms with regular application of chicken manure, Galinsoga seedling was nearly absent. Wichrowska and Jaskulski (2014) noted Galinsoga population decreases by $50 \%$ when manure was replaced by straw and mineral fertilization.

The application of plastic mulch covered about $60 \%$ of the field of study sites of Dieng. The mulch was installed to reduce weeding costs, soil erosion, and control rot disease. Kastanja (2015) stated that Galinsoga seeds undergo dormant under plastic mulch. In potato and cabbage fields of Kubang village, the average number of Galinsoga seedlings per square meter decreased from 56-2,550 in bare land to 0-38 seedlings in mulched-fields caused a yield reduction of Galinsoga from approximately $400-1,150 \mathrm{~kg} \mathrm{ha}^{-1}$ to 20 $50 \mathrm{~kg} \mathrm{ha}^{-1}$, respectively. Nevertheless, in potato fields in Kepakisan village farmers still able to collect Galinsoga shoots in mulched-field two months after the harvest of potato around July-August. Santosa et al. (2009) show that Galinsoga of both seedling and seed bank is absent in the tea plantation at altitude 480-1200 m above sea level. It is probable that under continuous shading like in the tea plantation, the Galinsoga lost the viability.

The present study demonstrated that Galinsoga is still important for vegetables in the mountainous area in Banjarnegara and Wonosobo Districts, although changes in the vegetable production technology might threaten its availability. Galinsoga is prospective as a future vegetable considering its wide distribution in Indonesia such as Java (Yuliadhi et al., 2013; Azalia et al., 2015; Ilmiyah, 2015), Tobelo-Maluku (Kastanja, 2015), Sumatera (Permana et al., 2013), and Bali (Yuliandhi et al., 2013; Sutomo, 2019). It was found at the cabbage field in Sembalun around Mt. Rinjani in Lombok during visitation in January 2017. The distribution of Galinsoga in Java is presented in Figure 1. The study also noted that lack of cooking skill determined the popularity of the consumption in Kuningan and young families in Wonosobo district. Therefore, promoting food sharing could be an important strategy to maintain the cooking skill of Galinsoga like in Banjarnegara communities.

\section{CONCLUSION}

G. parviflora was a common weed in the vegetable fields, and it was traditionally used as an indigenous vegetable in Banjarnegara and Wonosobo districts. It was harvested for self-consumption and sometimes traded locally. Increasing pesticide application in the farm, application of mulch, and chicken manure affected Galinsoga availability and consumption rate. In the future, it is important to study the culture technique and its nutrient content to improve utilization as an indigenous vegetable and medicinal plant in Indonesia.

\section{REFERENCES}

Ali, S., S. Zameer, M. Yaqoob. 2017. Ethnobotanical, phytochemical and pharmacological properties of Galinsoga parviflora (Asteraceae): A review. Trop. J. Pharmaceutical Res. 16:3023-3033. Doi: 10.4314/ tjpr.v16i12.29. 
Andarwulan, N., D. Kurniasih, R.A. Apriady, H. Rahmat, A.V. Roto, B.W. Bolling. 2012. Polyphenols, carotenoids, and ascorbic acid in underutilized medicinal vegetables. J. Funct. Foods 4:339-347.

Azalia, D., H. Setiawan, C. Retnaningdyah. 2015. Evaluation of ground arthropod structure in restoration area of Talangagung landfill as edutourism attraction, Kepanjen, Malang. J. Indonesian Tourism Dev. Studies 3:85-92.

Bazylko, A., K. Boruc, J. Borzym, A.K. Kiss. 2015. Aqueous and ethanolic extracts of Galinsoga parviflora and Galinsoga ciliata. Investigations of caffeic acid derivatives and flavonoids by HPTLC and HPLCDAD-MS methods. Phytochem. Lett. 11:394-398.

Canne, J.M. 1983. Cytological and morphological observations in galinsoga and related genera (Asteraceae). Rhodora 85:355-366.

Chipurura, B., M. Muchuweti, M. Bhebhe. 2013. An assessment of the phenolic content, composition and antioxidant capacity of selected indigenous vegetables of Zimbabwe. Acta Hortic. 979:611-620. Doi:10.17660/ActaHortic.2013.979.66.

Cruz-Garcia, G.S., L.L. Price. 2012. Weeds as important vegetables for farmers. Acta Soc. Bot. Poloniae 81:397-403. Doi:10.5586/asbp.2012.047.

Damalas, C.A. 2008. Distribution, biology, and agricultural importance of Galinsoga parviflora (Asteraceae). Weed Biol. Manag. 8:147-153. Doi:10.1111/j.14456664.2008.00290.x.

Das Mallik, B.B., B.D. Acharya, M. Saquib, M.K. Chettri. 2014. Allelopathic effect of Artemisia dubia extracts on seed germination and seedling growth of some weeds and winter crops. Ecoprint 21:23-30. Doi: 10.3126/eco.v21i0.11901.

Dudek, M.K., L. Dudkowski, A. Bazylko, S. Kaźmierski, A.K. Kiss. 2016. Caffeic acid derivatives isolated from the aerial parts of Galinsoga parviflora and their effect on inhibiting oxidative burst in human neutrophils. Phytochem. Lett. 16:303-310.

Guo, Z.Q., Y.G. Zhao, F.J. Zhang, R. Long, X.D. Meng, S.X. Xing, X.Y. Xu. 2008. Allelopathic effects of the invasive plant Galinsoga parviflora Cav.Ic.et Descr. on Brassica pekinensis Rupr., Raphanus sativus L., Lactuca sativa L. var. romana Hort. and Brassica Chinensis L. J. Hebei Normal Uni. Sci. Techn. 200803 (Available online: http://en.cnki.com.cn/Article en/CJFDTOTAL-HBNS200803002.htm).
Ilmiyah, R. 2015. Preference of Menochilus sexmaculatus (Coleoptera: Coccinellidae) on Weed of Cabbage (Brassica oleracea) in Desa Sumberbrantas Kecamatan Bumiaji Kota Batu. [Undergraduate Thesis]. Universitas Muhamadiyah Malang (Available online: http://karya-ilmiah.um.ac.id/index. php/biologi/article/view/43576).

Ivany, J.A., R.D. Sweet. 1973. Germination, growth, development, and control of Galinsoga. Weed Sci. 21:41-45.

Jang, J.W., J.C. Yang, S.Y. Jung, H.J. Lee, J.E. Yun, C. Chang, H.S. Hwang, K.S. Chang, S.H. Oh, Y.M. Lee. 2014. The distribution of vascular plants in Banronsan (Mt.) at Jeongse on Gangwon-do, Korea. J. Asia-Pacific Biodiv. 7:e30-e39. Doi:10.1016/ j.japb.2014.03.007.

Kabuce, N., N. Priede. 2010. NOBANIS-Invasive Allien Species Fact Sheet-Galinsoga quadriradiata. From: Online Database of the European Network on Invasive Allien Species-NOBANIS www.nobanis. org. Date of access 15 July 2016.

Kastanja, A.Y. 2015. Analysis of weed composition on vegetable fields. J. Agroforestri 10:107-114 (In Indonesian with English summary).

Kolli, S.K., R. Kumar, J. Suneetha, G. Hemanth. 2016. Reasons for farmers choosing Elephant Foot Yam in Kovvur Mandal, West Godavari, Andhra Pradesh, India. Biolife 4:179-183. Doi:10.17812/ blj.2016.4125.

Kucewicz, M., E. Gojlo. 2014. Influence of achene heteromorphism on life-cycle traits in the annual weed gallant soldier (Galinsoga parviflora Cav.). Flora - Morph. Distr. Funct. Ecol. Plants 209:649654.

Kutywayo, V., T.H. Been. 2006. Host status of six major weeds to Meloidogyne chitwoodi and Pratylenchus penetrans, including a preliminary field survey concerning other weeds. Nematology 8:647-657.

Leonti, M. 2012. The co-evolutionary perspective of the food-medicine continuum and wild gathered and cultivated vegetables. Gen. Res. Crop Evol. 59:12951302.

Lin, L.J., Q. Jin, Y.J. Liu, B. Ning, M.A. Liao, L. Luo. 2014. Screening of a new cadmium hyperaccumulator, Galinsoga parviflora, from winter farmland weeds using the artificially high soil cadmium concentration method. Environ. Toxicol. Chem. 33:2422-2428. 
Ma, Q., X. Yu, L. Lin, M. Liao. 2015. Intercropping different density of Galinsoga parviflora can increase Cadmium accumulation in Radish. International Conference on Advances in Energy and Environmental Science (ICAEES 2015):1424-1427.

Maroyi, A. 2013. Use of weeds as traditional vegetables in Shurugwi District, Zimbabwe. J. Ethnobiol. Ethnomed. 9:60-70.

Molina, M., J. Tardio, L. Aceituno-Mata, R. Morales, V. Reyes-Garcia, M. Pardo-de-Santayana. 2014. Weeds and food diversity: natural yield assessment and future alternatives for traditionally consumed wild vegetables. J. Ethnobiol. 34:44-67.

Mwesigwa, M., J. Semakula, P. Lusembo, J. Ssenyonjo, R. Isabirye, R. Lumu, T. Namirimu. 2015. Smallholder local chicken production and available feed resources in central Uganda. Uganda J. Agric. Sci. 16:107113.

Odhav, B., S. Beekrum, U.S. Akula, H. Baijnath. 2007. Preliminary assessment of nutritional value of traditional leafy vegetables in Kwazulu-Natal, South Africa. J. Food Comp. Anal. 20:430-435.

Oh, H.K., H.M. Kang, S.H. Choi. 2010. Classification type of vascular plants in Yeohangsan, Muhaksan and Palyongsan, Masan. J. Korean Nat. 3:199-211.

Perdana, E.O., Chairul, Z. Syam. 2013. Vegetation analysis of weed in red dragon fruit (Hylocereus polyrhizus L.) in Batang anai, Padang Pariaman, Sumatera Barat. J. Bio. UA. 2:242-248.

Patharaj, J., Kannan. 2019. Phytochemical analysis of gallant soldier (Galinsoga parviflora) Cav. (Asteraceae) from Nilgiris of India. Internat. J. Res. Pharmacy Pharmaceutical Sci. 2:76-78.

Rai, J.P.N., R. Tripathi. 1984. Allelopathic effects of Eupatorium riparium on population regulation of two species of Galinsoga and soil microbes. Plant Soil 80:105-117.
Santosa, E., N. Sugiyama, S. Kawabata. 2003. Reasons for farmer's decision to cultivate elephant foot yams in Kuningan District, West Java, Indonesia. Jpn. J. Trop. Agr. 47:83-89.

Santosa, E., S. Zaman, I.D. Puspitasari. 2009. Weed seed bank of tea plantation at different pruning years. J. Agron. Indonesia 7:46-54.

Santosa, E., U. Prawati, Sobir, Y. Mine, N. Sugiyama. 2015. Agronomy, utilization and economics of indigenous vegetables in West Java, Indonesia. J. Hort. Indonesia 6:125-134.

Setyawati, T., S. Narulita, I.P. Bahri, G.T. Raharjo. 2015. A Guide Book to Invasive Plant Species in Indonesia. Research, Development and Innovation Agency, Ministry of Environment and Forestry, Republic of Indonesia.

Shin, H.T., M.H. Yi, J.W. Yoon, J.W. Sung, G.S. Kim. 2012. Status of alien plant species in the Seongeup Folk Village in Jeju Island. J. Korean Nat. 5:299-304.

Surywanshi, V., R.N. Yadava. 2015. New potential allelochemicals from Galinsoga parviflora Cav. Chem. Sci. Rev. Lett. 4:405-413.

Sutomo. 2019. Diversity of weeds on bamboo seedling's media in Bali Botanical Garden. J. Biol. Udayana 23:16-25.

Wichrowska, D., D. Jaskulski. 2014. Effect of organic and mineral fertilization and soil fertilizer on the weed infestation of potato plantation. Acta Sci. Poloniae Agric. 13:61-71.

Yuliadhi, K.A., T.A. Phabiola, M. Sritamin. 2013. The influence of the presence of weeds on the population number of main pest of cabbage on the cabbage croppings. Agrotip 3:99-103 (In Indonesian with English summary). 